\title{
Impact of Nitrogen Levels and Planting Density on the Growth and Yield of Okra (Abelmoschus esculentus L. Moench)
}

\author{
${\text { Funda Yoldaş }{ }^{1, a^{*}} \text {, Şafak Ceylan }}^{1, b}$, İbrahim Duman ${ }^{2, c}$, Ömer Lütfü Elmaci $^{3, d}$, Eftal Düzyaman $^{2, e}$ \\ ${ }^{1}$ Ödemiş Vocational High School, Ege University, 35750 Ödemiş, İzmir, Turkey \\ ${ }^{2}$ Department of Horticulture, Agriculture Faculty, Ege University, 35100 Bornova/Izmir, Turkey \\ ${ }^{3}$ Department of Soil Science and Plant Nutrition, Agriculture Faculty, Ege University, 35100 Bornova/İzmir, Turkey \\ *Corresponding author
}

A R T I C L E I N F O A B S T R A C T

Research Article

The study was carried out to the effects of different plant densities and nitrogen levels on okra yield and plant development. Field trials were conducted in two locations, the training fields of the Ege University, Ödemiş Research and Training area, and Ege University Faculty of Agriculture, Menemen Research and Training Farm. The field layout was a split-plot design with 3 replicates,

Received : 07/03/2021

Accepted : 30/04/2021 where main plots consisted of nitrogen applications and sub-plots of plant densities. Fertilizer was applied in the form of Triple Superphosphate, Potassium Sulfate, Urea and Ammonium Nitrate. Five different nitrogen levels (F1: 0, F2: 40, F3: 80; F4: 120 and F5: $160 \mathrm{~kg} \mathrm{~N} \mathrm{ha}^{-1}$ ) and two different rows spacing (PD1: $15 \mathrm{~cm} \times 70 \mathrm{~cm}$ and PD2: $25 \mathrm{~cm} \times 70 \mathrm{~cm}$ ) have been tested. Yield and yield components, plant height at flowering, height of the first fruits, the number of leaves, the number of branches, the number of days from sowing to first flowering, the number of days from sowing to

Keywords:

Abelmoschus esculentus L. Nitrogen fertilizer

Yield

Growth

Planting density first harvest, plant height, foliation status, total yield, yield of plant, average fruit weight, fruit length, fruit diameter have been noted in the field experiments. Total yield ranged from 5923.8 to $12888.9 \mathrm{~kg} \mathrm{ha}^{-1}$ at the Ödemiş location, while it was $3363.3-5009.2 \mathrm{~kg} \mathrm{ha}^{-1}$ at the Menemen location. In conclusion, the highest yield is taken from F2 in both plant densities in Ödemiş. In Menemen, the highest yield is taken from the dose of F3 (80 kg Nha $\left.{ }^{-1}\right)$ and F4 $\left(120 \mathrm{~kg} \mathrm{Nha}^{-1}\right)$.

funda.yoldas@ege.edu.tr ibrahim.duman@ege.edu.tr e@eftal.duzyaman@ege.edu.tr

\section{(iD) https://orcid.org/0000-0001-6205-9751 (iD) https://orcid.org/0000-0003-0081-7208 (iD) https://orcid.org/0000-0001-8442-2590}

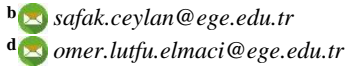

https://orcid.org/0000-0003-3897-169X iD https://orcid.org/0000-0002-6514-6479

(c) (1) (9) This work is licensed under Creative Commons Attribution 4.0 International License

\section{Introduction}

Okra (Abelmoschus esculentus L.) is one of the most important vegetable crops grown in Turkey, with is 31428 tons (Anonymous 2019). Consumption has been increasing, due to awareness of the health benefits of okra.

Yield of okra has been sustained by intensified cultural practices including the planting density, and increased use of fertilizer, compost and synthetic chemicals. Okra productivity can be determined by cultivar and plant population (Salau and Makinde 2015). Muenoke and Asiegbu, (1996) reported decreased pod yield per plant and yield components as population increased. Maximum fruit length, fruit weight, fruit number and yield per plant of the most extensive ranges have been recorded by various researchers (Singh, 1990; Weiner, 1990; Muenoke and Asiegbu, 1996; Ali, 1999; Anjum and Amjad, 1999; Olasantan, 2001; Kabura et al., 2002; Muenoke and Asiegbu, 2003; Manga and Mohammed, 2006; Salau and Makinde, 2015; Khanal at al., 2020; Adekya at al., 2020;
Regmi et al., 2020; Verma et al., 2020). Increasing plant population may result in growth and yield decrease per plant due to inter-and intraspecific plant competition. However, a higher population might compensate for plant density-induced decreased growth and yield (Salau and Makinde, 2015).

Nitrogen is the most essential element of plant nutrition. Sufficient nitrogen supply improves cell division and photosynthetic activity of the plant (Sharma and Yadav, 1996). Thus, nitrogen is often considered the most important limiting factor, for crop yields. Formation of each yield component depends strongly on the $\mathrm{N}$ supplied at each developmental stage throughout the life cycle of the plant (Zhang et al., 2007). However, it is important to use nitrogen fertilizer in optimum amounts. Unconsciously, the use of excessive amounts of nitrogen can cause a decrease in the quantity and quality of the product and increase input costs. it can also cause environmental pollution because $\mathrm{N}$ is very 
mobile in the soil and can be leaching and contaminated into groundwater (Gastal and Lemaire, 2002).

Some researchers used NPK fertilizers for the increase of growth, yield and yield attributes of okra. Significant increase in the growth and yield of okra was observed after the application of $\mathrm{N}$ and NPK. Nitrogen, phosphorus and potassium fertilizer applications increases vegetative growth, yield and quality characteristics (Verma et al., 1970; Singh, 1979; Hooda et al., 1980; Mani and Ramanathan, 1980; Fatokun and Chheda, 1981; Sherestha, 1983; Majanbu et al., 1985; 1986; Mishra and Pandy, 1987; Abusaleha and Shanmugavelu, 1988; Arora et al., 1991; Faraq and Damrany, 1994; Fondane and Bhatia, 1995; Haque and Jakhro, 1996; Katung et al., 1996; Anjum and Amjad, 1999; Khan et al., 2000; Amjad et al., 2002; Kabura et al., 2002; Mouneke and Asiegbu, 2003; Manga and Mohammed, 2006; Rahman and Akter, 2012: Khanal at al., 2020, Adekya at al., 2020, Regmi et al., 2020, Verma et al., 2020). Also, several researchers have reported linear increase in green pod yield of okra with the application of $\mathrm{N}$ from 56 to 150 $\mathrm{kg} / \mathrm{ha}$ (Majanbu et al., 1985; Singh, 1995: Khanal at al., 2020; Adekya at al., 2020, Regmi et al., 2020; Verma et al., 2020). Firoz (2009) reported that the highest yield (16.73 $\mathrm{ha}^{-1}$ ) was obtained after the application of $100 \mathrm{~kg} \mathrm{~N} \mathrm{ha}^{-1}$ which was statistically identical to $120 \mathrm{~kg} \mathrm{~N} \mathrm{ha}^{-1}$.

This study was undertaken to evaluate the effects of different plant densities and nitrogen levels on plant development and yield in okra in two different locations.

\section{Materials and Methods}

\section{Research Area}

The study was conducted at two locations (Ege University Odemis Research and Training area-Odemis location (L1)-, and Ege University Faculty of Agriculture, Menemen Research and Training Farm -Menemen location (L2) -. Research field of altitude for L1: $136 \mathrm{~m}$ and $22 \mathrm{~m}$ for Menemen location.

\section{Meteorological Data of Research Areas}

For L1 and L2 locations, monthly averages of air temperature and total rainfall (Anonymous, 2018a; Anonymous, 2018b) are presented in Table 1. When Table 1 is examined, it is understood that a typical Mediterranean climate is dominant in the trial area in L1. October to April is rainy period. The climatic characteristic of L 2 has not been a limiting factor in the cultivation of okra plant.

\section{Establishment of Field Experiment and Applications}

Field trials were conducted in two locations (L1 and L2). The field layout was a split-plot design with 3 replicates, where main plots consisted of nitrogen applications and subplots of plant densities. Five different nitrogen levels (F1: 0, F2: 40, F3: 80; F4: 120 and F5: $160 \mathrm{~kg} \mathrm{~N} \mathrm{ha}^{-1}$ ) and two different within row spacing (PD1: $15^{*} 70 \mathrm{~cm}$ and PD2: $25^{*} 70 \mathrm{~cm}$ ) have been tested. In the research it was used basic fertilizer as $\mathrm{P}_{2} \mathrm{O}_{5}$ in the form of the TSP to $80 \mathrm{~kg} \mathrm{ha}^{-1}$ and 120 $\mathrm{kg} \mathrm{ha}{ }^{-1} \mathrm{~K}_{2} \mathrm{O}$ fertilizers are given in the form of $\mathrm{K}_{2} \mathrm{SO}_{4}$. Fertilizer was applied as a band. All of phosphorus, $60 \%$ potassium and $25 \%$ of nitrogen were applicate with sowing. Two of the remaining nitrogen and potassium was applied after 20 days, seedlings from the emergence. The other half was applied after 40 days. Nitrogen was applied as Urea
(46\%) form in plantation and the other part was applied as Ammonium Nitrate (26\%).

\section{Soil Properties of the Research Site}

The soil samples were taken from $0-20 \mathrm{~cm}$ depth to determine soil properties of the both locations. The physical and chemical properties of the soils are shown in Table 2 .

Table 2 shows that the soil of L1 was neutral, had no salinity problem, was low in $\mathrm{CaCO}_{3}$ and organic matter and had a loamy sandy texture. The total $\mathrm{N}$ and available $\mathrm{K}$ contents of the soil were low and $\mathrm{P}$ was rich.

In L2 experiment field soil was medium alkaline reaction. It was rich in lime, poor in organic matter and had a loamy sandy texture. Total $\mathrm{N}$, available $\mathrm{P}$ and $\mathrm{K}$ amounts were low (Güneş et al., 2000; Chapman and Pratt, 1961).

\section{Cultural Practices}

\section{Sowing}

Kaymakçı okra variety was used in this the study. This variety is grown as for canned in the region. Seeds were sowed on 26 April in both locations. All cultural practices, irrigation, weed control, etc. in both locations was applied on all parcels equal. The seeds were sown into the soil by hand. Inter rows were $15 \mathrm{~cm}$ (PD1) and $25 \mathrm{~cm}$ (PD2), row distance was $70 \mathrm{~cm}$.

\section{Maintenance Procedures}

In the study, during plant growth, irrigation, hoeing and weed control were made according to Vural et al. (2000); Yoldas et al. (2018). In periods in which the trial was conducted, any disease or harmful effects were observed in okra plants. Therefore, it has been done to fight against them, and weeds chemical control has not been applied to the plots. Only some dominant and large weed (Anthemis sp., Avena fatua, etc.) is rooted hands and anchor.

Harvest

To determine the yield and yield components; 250gram samples (from large fruits) were taken from each plot. Fruits have been harvested twice a day regularly.

\section{Soil Physical, Chemical, Analysis Methods}

Soil samples $(0-20 \mathrm{~cm}$ depth) were taken from all treatments and pH (Jackson, 1967), total soluble salt (Anonymous, 1951), $\mathrm{CaCO}_{3}$ (Kacar, 1995), Organic matter content (Reuterberg and Kremkurs, 1951) and texture (Bouyoucos, 1962) were determined. Total $\mathrm{N}$ was determined according to Bremner (1965), available K was determined after extracting with $1 \mathrm{~N} \mathrm{NH}_{4} \mathrm{OAc}$ by flame photometer (Jackson, 1967; Atalay et al., 1986). Available $\mathrm{P}$ was measured by colorimeter after extracting with distilled water (Bingham 1949).

The Scope of the Research Examined the Characters

Plant height at flowering $(\mathrm{cm})$, height of the first fruits $(\mathrm{cm})$, the number of leaves (unit), the number of branch (unit), the number of days from sowing to first flowering (day), the number of days from sowing to first harvest (day), plant height $(\mathrm{cm})$, foliation status (low, medium, good), total yield $\left(\mathrm{kg} \mathrm{ha}^{-1}\right)$, yield of plant $(\mathrm{g})$, average fruit weight $(\mathrm{g})$, fruit length $(\mathrm{cm})$, fruit diameter $(\mathrm{cm})$ has been noted in the field experiments in both locations. All measurements were performed according to standard after seedling emergence. 
Table 1. Monthly averages of air temperature and total rainfall of the research areas.

\begin{tabular}{l|cccc}
\hline \multirow{2}{*}{ Months } & \multicolumn{2}{|c}{ Odemis $(\mathrm{L1})$} & \multicolumn{2}{c}{ Menemen $(\mathrm{L} 2)$} \\
\cline { 2 - 5 } & Air temperature $\left({ }^{\circ} \mathrm{C}\right)$ & Total rainfall $(\mathrm{mm})$ & Air temperature $\left({ }^{\circ} \mathrm{C}\right)$ & Total rainfall $(\mathrm{mm})$ \\
\hline January & 5.6 & 19.9 & 9.3 & 17.2 \\
February & 8.2 & 54.0 & 9.6 & 24.2 \\
March & 11.0 & 15.0 & 12.6 & 38.4 \\
April & 16.2 & 35.2 & 15.1 & 0.4 \\
May & 20.5 & 31.7 & 21.5 & 42.8 \\
June & 25.4 & 7.0 & 26.6 & 5.0 \\
July & 27.9 & - & 29.0 & - \\
August & 28.4 & - & 28.0 & - \\
September & 22.8 & 6.7 & 23.0 & 61.0 \\
October & 17.9 & 74.5 & 18.1 & 24.2 \\
November & 10.2 & 138.5 & 11.4 & 6.0 \\
December & 6.8 & 126.2 & 8.2 & 219.2 \\
X- $\Sigma$ & 16.7 & 508.7 & 17.7 & \\
\hline
\end{tabular}

Table 2. Some physical and chemical properties of trial soils

\begin{tabular}{|c|c|c|c|c|c|c|c|c|c|c|}
\hline \multirow{2}{*}{ Locations } & \multirow{2}{*}{$\mathrm{pH}$} & \multirow{2}{*}{ Total salt $\%$} & \multirow{2}{*}{$\mathrm{CaCO}_{3} \%$} & \multirow{2}{*}{ Sand \% } & \multirow{2}{*}{ Mil \% } & \multirow{2}{*}{ Clay } & \multirow{2}{*}{ Texture } & \multirow{2}{*}{ O.M } & \multicolumn{2}{|c|}{ Available $\left(\mathrm{mg} \mathrm{kg}^{-1}\right)$} \\
\hline & & & & & & & & & Total N & $\mathrm{P} \quad \mathrm{K}$ \\
\hline$\overline{\mathrm{L} 1}$ & 7.09 & $<0.03$ & 0.61 & 76.04 & 20.28 & 3.68 & Loamy-sand & 0.99 & 0.06 & $14 \quad 140$ \\
\hline $\mathrm{L} 2$ & 7.88 & 0.051 & 6.58 & 50.40 & 37.28 & 12.32 & Loamy-sand & 1.29 & 0.034 & 0.23127 .4 \\
\hline
\end{tabular}

Table 3. Effect of $\mathrm{N}$ fertilizer rates and Planting Density on okra growth (L1)

\begin{tabular}{|c|c|c|c|c|c|c|c|c|}
\hline \multicolumn{9}{|c|}{ Treatment/PHF (cm)HFF (cm)NL (unit/plant)NB (unit/plant)NDFF (day)NDFH (day)PH-(cm)FS (low, medium, good) } \\
\hline PD1F1 & 34.88 & 12.89 & $48.97^{\mathrm{bd}}$ & 5.83 & 53.67 & 58.00 & 97.53 & Medium \\
\hline PD1F2 & 39.11 & 15.50 & $31.77^{\mathrm{cd}}$ & 5.87 & 54.67 & 59.33 & 93.60 & Medium \\
\hline PD1F3 & 27.33 & 13.39 & $53.97 \mathrm{ac}$ & 6.07 & 56.00 & 60.33 & 103.97 & Good \\
\hline PD1F4 & 31.44 & 17.97 & $26.73^{d}$ & 6.97 & 55.00 & 59.33 & 100.07 & Low \\
\hline PD1F5 & 32.55 & 15.22 & $41.53^{b d}$ & 5.63 & 55.33 & 59.67 & 95.27 & Medium \\
\hline PD2F5 & 35.89 & 15.55 & $48.30^{\mathrm{bd}}$ & 7.87 & 55.67 & 61.00 & 90.17 & Medium \\
\hline PD2F4 & 34.50 & 14.94 & $26.50^{d}$ & 5.97 & 54.33 & 59.67 & 107.07 & Low \\
\hline PD2F3 & 32.55 & 15.50 & $53.20^{\mathrm{ac}}$ & 5.40 & 55.67 & 59.33 & 99.07 & Good \\
\hline PD2F2 & 36.33 & 15.77 & $59.83^{\mathrm{ab}}$ & 6.87 & 55.00 & 58.67 & 111.53 & Good \\
\hline PD2F1 & 31.89 & 14.25 & $73.67^{\mathrm{a}}$ & 6.97 & 52.67 & 58.33 & 83.93 & Good \\
\hline Average & $33.65^{\mathrm{ns}}$ & $15.10^{\mathrm{ns}}$ & $46.45^{\text {** }}$ & $6.34^{\mathrm{ns}}$ & $54.80^{\text {ns }}$ & $59.37^{\mathrm{ns}}$ & $98.22^{\mathrm{ns}}$ & \\
\hline
\end{tabular}

$\mathrm{x}=$ Duncan's multiple classification test, $* *: \mathrm{P}<0.01$, *: $\mathrm{P}<0.05$ n.s.: not significant, (Plant height at flowering (cm)-PHF-Height of the first fruits (cm)HFF-Number of leaves (unit/plant)-NL-The number of branch (unit/plant)-NB-The number of days from sowing to first flowering (day)-NDFF-The number of days from sowing until the first harvest (day)-NDFH-Plant Height (cm)-PH-Foliation status (low, medium, good)-FS-)

\section{Data Analysis}

The findings from the trials have been analyzed separately in locations. Data were analyzed with SPSS 13.0 statistical package program are determined based on differences between the mean Duncan multivariate analyses (Efe et al., 2000).

\section{Results}

\section{L1 Location Data}

Effect of $N$ Fertilizer Rates and Planting Density on Okra Growth (L1)

The data of planting density and fertilizing is given in Table 3. The effect of the combination on plant height in flowering, height of first fruits, the number of branches, the number of days from sowing to first flowering, the number of days from sowing to first harvest and plant height were statistically insignificant. The effect of applications on number of leaves was statistically significant $(\mathrm{P} \leq 0.01)$.

The highest value (73.67 units) was recorded in the combination of PD2F1, when the minimum value was obtained from PD2F4 (26.50 units). The values of the number of days from sowing to first flowering were examined, PD1F3 in the first place with 56 days, while the application of PD2F1 was ranked last as the minimum value with the value 52.67 day. Compared to applications in terms of the number of days to first harvest, the values are close to each other the number of days of sowing until the first harvest has been changed 58-61 day.

Effect of $N$ Fertilizer Rates and Planting Density on Yield and Yield Components (L1)

The values for yield and yield components obtained from L1 location are given in Table 4. Total yield values were found safely important $(\mathrm{P} \leq 0.05)$ in $\mathrm{L} 1$. The highest value has been achieved from PD1F1 (12888.9 kg ha-1), lowest value has been achieved from PD2F5 $(4561.9 \mathrm{~kg}$ $\mathrm{ha}^{-1}$ ) and the average value is $7509.5 \mathrm{~kg} \mathrm{ha}^{-1}$.

The values obtained at L1 the difference between the averages of fruit weight applications in terms of $\mathrm{P} \leq 0.05$ to be significant were found safely. The highest value $(4.98 \mathrm{~g})$ reached in PD2F2 application. In PD1F4 application, the fruit weight was determined as $3.41 \mathrm{~g}$. 
Table 4. Effect of $\mathrm{N}$ fertilizer rates and Planting Density on yield and yield components (L1)

\begin{tabular}{|c|c|c|c|c|c|c|}
\hline Treatments & $\begin{array}{c}\text { Total yield } \\
\left(\mathrm{kg} \mathrm{ha}^{-1}\right)\end{array}$ & $\begin{array}{l}\text { ield of plar } \\
\text { (g/plant) }\end{array}$ & $\begin{array}{l}\text { imber of fru } \\
\text { (per plant) }\end{array}$ & $\begin{array}{l}\text { frui } \\
(\mathrm{g})\end{array}$ & $\begin{array}{l}\text { e fruit } \\
(\mathrm{cm})\end{array}$ & $\begin{array}{l}\text { fruit diameter } \\
(\mathrm{cm})\end{array}$ \\
\hline$\overline{\text { PD1F1 }}$ & $8634.9^{b}$ & 90.67 & 23.33 & $3.85^{\mathrm{bc}}$ & 4.30 & 1.02 \\
\hline PD1F2 & $12888.9^{a}$ & 135.33 & 31.17 & $4.37^{\mathrm{ab}}$ & 4.60 & 1.02 \\
\hline PD1F3 & $8000.0^{\mathrm{b}}$ & 84.00 & 23.50 & $3.53^{\mathrm{bc}}$ & 4.74 & 1.04 \\
\hline PD1F4 & $8000.0^{\mathrm{b}}$ & 84.00 & 24.83 & $3.41^{\mathrm{c}}$ & 3.75 & 1.03 \\
\hline PD1F5 & $7095.2^{\mathrm{b}}$ & 74.50 & 20.17 & $3.68^{\mathrm{bc}}$ & 5.19 & 1.14 \\
\hline PD2F5 & $4561.9^{\mathrm{b}}$ & 79.83 & 21.00 & $3.88^{\mathrm{bc}}$ & 4.40 & 1.06 \\
\hline PD2F4 & $6047.6^{b}$ & 105.83 & 29.00 & $3.69^{\mathrm{bc}}$ & 4.64 & 1.09 \\
\hline $\mathrm{PD} 2 \mathrm{~F} 3$ & $6152.4^{\mathrm{b}}$ & 107.67 & 26.00 & $3.99^{\mathrm{bc}}$ & 5.14 & 1.11 \\
\hline $\mathrm{PD} 2 \mathrm{~F} 2$ & $7790.5^{b}$ & 136.33 & 27.67 & $4.98^{\mathrm{a}}$ & 4.37 & 1.12 \\
\hline PD2F1 & $5923.8^{\mathrm{b}}$ & 103.67 & 28.83 & $3.64^{\mathrm{bc}}$ & 4.27 & 1.10 \\
\hline Average & $7509.5^{*}$ & $100.18^{\mathrm{ns}}$ & $25.55^{\mathrm{ns}}$ & $3.90^{*}$ & $4.54^{\mathrm{ns}}$ & $1.07^{\mathrm{ns}}$ \\
\hline
\end{tabular}

$\mathrm{x}=$ Duncan's multiple classification test, $* *: \mathrm{P}<0.01$, *: $\mathrm{P}<0.05$, n.s.: not significant

Table 5. Effect of $\mathrm{N}$ fertilizer rates and Planting Density on okra growth (L2)

\begin{tabular}{|c|c|c|c|c|c|c|c|c|}
\hline Treatments & $\overline{\mathrm{PHF}(\mathrm{cm})}$ & $\overline{\mathrm{HFF}}(\mathrm{cm})$ & $\overline{\mathrm{JL} \text { (unit/plant)] }}$ & NB (unit/plant & NDFF (day) & NDFH (day & y) $\mathrm{PH}-(\mathrm{cm})$ & $\overline{\mathrm{w}, \text { medium, good) }}$ \\
\hline$\overline{\text { PD1F1 }}$ & 32.47 & 7.47 & $15.20^{\mathrm{bc}}$ & 1.33 & 46.67 & $53.00^{\mathrm{b}}$ & $47.80^{\mathrm{cd}}$ & medium \\
\hline PD1F2 & 29.87 & 8.40 & $15.13^{\mathrm{bc}}$ & 1.33 & 45.33 & $53.67^{\mathrm{a}}$ & $47.87^{\mathrm{cd}}$ & medium \\
\hline PD1F3 & 33.47 & 7.60 & $17.00^{\mathrm{b}}$ & 2.11 & 44.33 & $54.00^{\mathrm{a}}$ & $57.20^{\mathrm{bd}}$ & medium \\
\hline PD1F4 & 37.80 & 8.00 & $22.40^{\mathrm{a}}$ & 2.67 & 43.67 & $54.00^{\mathrm{a}}$ & $78.53^{\mathrm{ab}}$ & good \\
\hline PD1F5 & 34.80 & 7.47 & $22.87^{\mathrm{a}}$ & 2.11 & 43.00 & $54.00^{\mathrm{a}}$ & $79.53^{\mathrm{ab}}$ & good \\
\hline PD2F5 & 36.27 & 7.47 & $23.73^{\mathrm{a}}$ & 2.22 & 44.00 & $52.67^{\mathrm{b}}$ & $88.33^{\mathrm{a}}$ & good \\
\hline PD2F4 & 28.47 & 8.73 & $21.80^{\mathrm{a}}$ & 2.44 & 46.33 & $53.00^{\mathrm{b}}$ & $72.47^{\mathrm{ac}}$ & good \\
\hline PD2F3 & 33.33 & 7.60 & $19.93^{\mathrm{ab}}$ & 2.00 & 41.33 & $53.67^{\mathrm{a}}$ & $60.60^{\text {bd }}$ & good \\
\hline PD2F2 & 32.47 & 7.00 & $15.60^{\mathrm{bc}}$ & 2.11 & 44.00 & $54.00^{\mathrm{a}}$ & $44.73^{\mathrm{cd}}$ & Medium \\
\hline PD2F1 & 26.60 & 7.67 & $11.60^{\mathrm{c}}$ & 1.89 & 46.00 & $53.00^{\mathrm{b}}$ & $41.27^{\mathrm{d}}$ & Medium \\
\hline Average & $32.55 \mathrm{~ns}$ & $7.74 \mathrm{~ns}$ & $18.53 * *$ & $2.02 \mathrm{~ns}$ & $44.47 \mathrm{~ns}$ & $53.50 * *$ & $61.83 * *$ & \\
\hline
\end{tabular}

$\mathrm{x}=$ Duncan's multiple classification test, **: $\mathrm{P}=0.01$ important, *: $\mathrm{P}=0.05$ important, $\mathrm{ns}$ : no signification, (Plant height at flowering (cm)-PHF-Height of the first fruits (cm)-HFF-Number of leaves (unit/plant)-NL-The number of branch (unit/plant)-NB-The number of days from sowing to first flowering (day)-NDFF-The number of days from sowing until the first harvest (day)-NDFH-Plant Height (cm)-PH-Foliation status (low, medium, good)-FS-)

Table 6. Effect of N fertilizer rates and Planting Density on okra growth (L2)

\begin{tabular}{l|cccccc}
\hline Treatments & $\begin{array}{l}\text { Total yield Yield of plant Number of fruit } \\
\left(\mathrm{kg} \mathrm{ha}^{-1}\right)\end{array}$ & $\begin{array}{c}\text { Average fruit weight } \\
(\mathrm{g} / \mathrm{glant})\end{array}$ & $\begin{array}{c}\text { Average fruit length Average fruit diameter } \\
(\mathrm{cm})\end{array}$ & $\begin{array}{c}\text { (p) }) \\
(\mathrm{cm})\end{array}$ \\
\hline PD1F1 & 3642.6 & 52.23 & 13.67 & 4.08 & 4.67 & 1.31 \\
PD1F2 & 3897.8 & 84.41 & 13.41 & 3.55 & 4.15 & 1.38 \\
PD1F3 & 4038.3 & 46.03 & 12.46 & 4.86 & 4.47 & 1.42 \\
PD1F4 & 5009.2 & 55.65 & 16.40 & 4.73 & 4.97 & 1.56 \\
PD1F5 & 4983.3 & 64.51 & 17.74 & 4.25 & 4.92 & 1.42 \\
PD2F5 & 4917.1 & 90.66 & 23.83 & 5.04 & 5.11 & 1.47 \\
PD2F4 & 4620.0 & 108.76 & 24.30 & 4.47 & 5.59 & 1.45 \\
PD2F3 & 4431.0 & 78.84 & 20.38 & 5.27 & 5.10 & 1.50 \\
PD2F2 & 3363.3 & 81.04 & 16.93 & 4.10 & 5.09 & 1.39 \\
PD2F1 & 3748.3 & 111.99 & 18.83 & 3.18 & 3.60 & 1.24 \\
\hline Average & $4265.1^{\mathrm{ns}}$ & $77.41^{\mathrm{ns}}$ & & $4.35^{\mathrm{ns}}$ & $1.41^{\mathrm{ns}}$ & \\
\hline
\end{tabular}

$\mathrm{X}=$ Duncan's multiple classification test, **: $\mathrm{P}=0.01$ important, *: $\mathrm{P}=0.05$ important, ns: no signification

\section{L2 Location Data}

Effect of $N$ Fertilizer Rates and Planting Density on Okra Growth (L2)

The values of L2 are given in Table 5. Plant height at flowering, the height of first fruits, the number of branches, the number of days from sowing to first flowering of the combination of the application were found to be statistically insignificant effect.

The effect of the combinations of application on number of leaves, the number of days of sowing until the first harvest and final plant height was statistically significant $(\mathrm{P} \leq 0.01)$. The effect of the application in terms of the number of days to first harvest was statistically significant $(\mathrm{P} \leq 0.01)$. The values are close to each other and the number of days to first harvest day has been changed between 52.67 and 54.00 days.

Effect of $N$ Fertilizer Rates and Planting Density on Yield and Yield Components (L2)

In L2 location, the values for yield and yield components are given in Table 6. As shown in Table 6, the effect of application on yield and yield components were found to be statistically insignificant. Menemen location in terms of total yield values obtained when examining applications, the highest value has been reached from PD1F4 (5009.2 $\mathrm{kg} \mathrm{ha}^{-1}$ ).

The location average has been determined as $4265.1 \mathrm{~kg}$ $\mathrm{ha}^{-1}$. The resulting yield per plant was not a significant difference in terms of the statistics. The value of the highest 
yield per plant is reached in PD2F1 (111.99 g) when the minimum value was recorded from the application PD1F3 $(46.03 \mathrm{~g})$. In terms of the average fruit size there was no significant difference in statistical terms.

\section{Discussion, Conclusions and Recommendations}

The effect of fertilizer and planting density application were not found to be statistically significant on the number of days until first flowering in both locations. Birbal et al. (1995) and Ali, (1999) reported that plant density did not have any impact on the number of days of flowering. For this reason, the results of the study are consistent with previous studies (Ali, 1999; Birbal et al., 1995; Amjad, 2002). The number of flowerings until the first day as the control plot in determining 53.07 days, this value is recorded in other applications in the range of 51.07 to 55.93 days (Khan et al., 2000). These values correlated with the values obtained in our study. The highest yield was obtained in the dense spacing. In both planting density applications in general it can be said that the increased value of high fertilizer dose of fruit size. However, the effect of planting density on fruit size has been determined and the maximum value has been obtained the largest planting density (PD2). These results are in concordance with the results presented by. Singh (1990) have reported the most sowing distances, reaching maximum fruit length. Number of pods per plant was affected by cultivar, planting density, year, and the cultivar by year interaction. Pod yield per plant was affected by planting density, year, and the cultivar by year interaction (Salau and Makinde, 2015). The number of fruits per plant increased with increasing planting density which found by Amjad et al. (2002); Salau and Makinde (2015) is parallel to our results. Olasantan (1999) reported that, different nitrogen rates $(0,60,120$ $\mathrm{kg} / \mathrm{ha}$ ) increase the number of fruits per plant in okra. It is observed that the number of these values obtained in our study is lower. Singh (1990); Birbal et al. (1995); Ali (1999) stated that more heavy fruits as the distance increases between the plants have occurred. The effect of applications on the total yield for L1 was found to be significant $(\mathrm{P} \leq 5 \%)$. Total yield and yield per plant depends on plant density. For this reason, high efficiency is being imported in often sowing (because of the presence of more plants) and wide range of sowing, the yield decreases. The increase in yield per hectare due to increased planting density indicated that increased population made up for reduced yield per plant. Maximum yield of okra due to increased densities has been reported with other cultivars in a different environment (Pandey and Sing, 1979; Sarnaik et al., 1986; Khan and Jaisal, 1998; Salau and Makinde, 2015). The highest total yield is obtained by often sowing has been identified by some researchers (Amjad et al., 2002; Singh, 1990; Ali, 1999). Expanding plant distance, the plant takes to more nutrients and minor development increases, and consequently also an increase in the number of fruits per plant for each plant has been observed. Excessive $\mathrm{N}$ rates in the yield fruit is fall, probably, depend on the number of fruits per plant. There were problems in production of okra when the rate of nitrogen excessive and above on $120 \mathrm{~kg} \mathrm{ha}^{-1}$ and the yield was decrease. It is connected to the reduced number of fruits per plant.
As a result, the necessity of fertilization in okra cultivation in ecological conditions of the region, considering the positive effects on soil productivity, F3 (80 $\left.\mathrm{kg} \mathrm{ha}^{-1}\right)$ and F4 (120 kg ha-1) of fertilizer may indicate that the dosage is appropriate. The highest yield is taken from $\mathrm{F} 2$ in both plant densities in L1. In L2, the highest yield is taken from the dose of F3 $\left(80 \mathrm{~kg} \mathrm{~N} \mathrm{ha}^{-1}\right)$ and F4 (120 kg N $\left.\mathrm{ha}^{-1}\right)$. The reason for this, the soils of the experimental field in $\mathrm{L} 1$ is $\mathrm{N}$ contain a total of approximately 2 times according to $\mathrm{L} 2$.

Okra is an important vegetable in the Aegean region as the proposed frequency and fertilizer doses at these locations as friendly to the environment and human health will continue to provide profit to the farmer.

\section{Acknowledgments}

This research was work is partially supported by Scientific Research Project Commission of Ege University; Contact no: 07/OMYO/001.

\section{References}

Abusaleha and Shanmugavelu KG. 1988. Studies on the effect of organic v/s inorganic source of nitrogen on growth, yield and quality of okra [Abelmoschus esculentus (L.) Monech]. Ind. J. Hortic. 45: 312-318.

Adekiya AO, Ejue WS, Olayanju A, Dunsin O, Aboyeji CM. Aremu C, Adegbite K, Akinpelu O. 2020. Different organic manure sources and NPK fertilizer on soil chemical properties, growth, yield and quality of okra. Sci Rep. 2020 Sep 30; 10(1):16083. doi: 10.1038/s41598-020-73291-x. Ali A. 1999. Response of okra (Abelmoschus esculentus L. Moench) to phosphorus and spacing, M.Sc. Thesis, Dept. of Horticulture, Univ. of Agriculture, Faisalabad.

Amjad M, Sultan M, Anjum MA, Chaudhry MA. 2002. Response of Okra (Abelmoschus esculentus L. Moench) to Various Doses of N\&P and Different Plant Spacing. Journal of Research (Science), Bahauddin Zakariya University, Vol.13, No.1, 19-29 pp.

Anjum MA, Amjad M. 1999. Response of okra (Abelmoschus esculentus L. Moench) to different levels of N, P and K fertilizers. Pak. J. Biol. Sci., 2: 794-796.

Anonymous 1951. U.S. Soil Survey Staff, Soil Survey Manual, U.S. Dept. Agr. Handbook 18. U.S. Govt. Printing Office, Washington DC. USA.

Anonymous 2018a. Odemis Meteorological Station, Izmir, Turkey.

Anonymous 2018b. Menemen Meteorological Station, Izmir, Turkey.

Anonymous 2019. http://www. tuik.gov.tr.

Arora SK, Kumar N, Sharma BR, Kumar N. 1991. Effect of Nitrogen and Phosphorus Fertilization on Growth and Yield Components in Okra. J. Hort. Sci. 20: 261-266.

Atalay IZ, Kiliç R, Anaç D, Yokas I. 1986. Potassium status of these soils rendzina soils of gediz basin and the amount of available potassium in the determination of methods to be used. Ege University, Agriculture Faculty, Soil Department. Bilgehan Publications, Izmir. $25 \mathrm{~s}$.

Bingham FT. 1949. Soil Test for Phosphate. California Agriculture 3(8):11-14.

Birbal RK, Nehra N, Malik YS. 1995. Effect of spacing and nitrogen on fruit yield of okra cv. Varsha Uphar, Haryana Univ. J. Res., 25: 47-51.

Bouyoucos FJ. 1962. Hydrometer Method. Improved for Making. Particle Size Analysis of Soil Agronomy Journal Vol: 54(5): 464-465. 
Bremner JM. 1965. Total nitrogen. Methods of soil analysis. Part 2. Chemical and microbiological properties. American Society of Agronomy, Madison, Wisconsin, pp.1149-1178.

Chapman HD, Pratt PF. 1961. Methods of analysis for soils, plants and waters. Division of Agricultural Sciences, University of California, Riverside.

Faraq IA, Damrany AM. 1994. The response of two okra cultivars to NPK levels and spacing on growth, yield and quality. Assiut J. Agric. Sci., 25: 99-117.

Fatokun CA, Chheda HR. 1981. The effect of nitrogen and phosphorus on yield and chemical composition of okra (Abelmoschus esculentus L. Moench). Paper presented at the $6^{\text {th }}$ African Horticulture Symposium, Ibadan, Nigeria.

Firoz ZA. 2009. Impact of Nitrogen and Phosphorus on the Growth and Yield of Okra (Abelmoschus esculentus L.) in Hill Slope Condition. Bangladesh J. Agr. Res. 34(4): 713-722.

Fondane SU, Bhatia FL. 1995. Response of Okra Phenotypes to Different Environments. Punjabrao Krishi Vidyapeeth, Maharashtra, India. PKV. Res. J. 19: 143-146.

Gastal F, Lemaire G. 2002. Nitrogen uptake and distribution in crops: an agronomical and ecophysiological perspective. J Exp Bot 53: 789-799

Güneş A, Alpaslan M, Inal A. 2000. Plant Nutrition and Fertilization. Ankara University, Faculty of Agriculture, Publication No. 1514, Textbook, 467, Ankara.

Haque IU, Jakhro AK. 1996. Soil and Fertilizer Nitrogen. Soil Sci. pp. 262. National Book Foundation Islamabad.

Jackson ML. 1967. Soil Chemical Analysis Prentice Hall, Inc, Englewood Cliffs. N.J. USA.

Kabura BH, Kwavi DJ, Dada YM. 2002. Effect of Nitrojen Supplementation on Yield and Quality of Okra Abelmoschus esculentus L. Moench Varieties in Semi-Arid Region of Nigeria. - In Umec, V.C. and J.A. Fagbayide (eds) Proceedings of Horticultural Society of Nigeria.

Kacar B. 1995. Plant and Soil Analysis. University of Nebraska College of Agriculture. Department of Agronomy. Lincoln. Nebreska. USA.

Katung MD, Olanrewaju JD, Gupta US, Kureh I. 1996. Fruit and seed yields of okra as influenced by farmyard manure and nitrogen fertilizer. Proc. $14^{\text {th }}$ HORTSON Cent. Ago-Iwoye.

Khanal S, Dutta JP, Yadav RK, Pant KN, Shrestha A, Joshi P. 2020. Response of Okra [Abelmoschus Esculentus (L.) Moench] to Nitrogen Dose and Spacing on Growth and Yield under Mulch Condition, in Chitwan, Nepal. Journal Clean WAS (JCleanWAS) 4(1): 40-44

Khan AR, Jaisal RC. 1998. Effect of Nitrogen, plant spacing and green fruit pickings on the seed production of okra. Veg. Sci. 15(1):8-14.

Khan H, Khan M, Rasul K, Majeed A, Safi AF. 2000. Effect of Different Levels of Nitrogen Alone and in Combination with Constant Doses of Phosphorus and Potassium on Growth and Yield of Okra (Ambelmoschus esculentus L.) cv. T-13 under the Agro-climatic Conditions of Mingora, Swat. Pakistan Journal of Biological Sciences 3(12):2101-2104.

Lee J, Le S. 2014. Correlations between soil physico-chemical properties and plant nutrient concentrations in bulb onion grown in paddy soil. Scientia Horticulture 179: 158-162.

Majanbu IS, Ogunlela VB, Ahmed MK, Olarewaju JD. 1985. Response of two okra (Abelmoschus esculentus L. Moench) varieties to fertilizers: yield and yield components as influenced by nitrogen and phosphorus application. Fertilezer Research. 6: 257-267.

Majanbu IS, Ogunlela VB, Ahmed MK. 1986. Response of two okra (Abelmoschus esculentus (L). Moench) varieties to fertilizers: growth and nutrient concentration as influenced by nitrogen and phosphorus application. Nigeria. Fertilizer Research 8: 297-306.

Manga AA, Mohammed SF. 2006. Effects of Plant Population and N Levels on Growth and Yield of Okra (Abelmoschus esculentus (L.) Moench). Adv. Hort. Sci., 2006, 20(2): 137-139.
Mishra HP, Pandy RF. 1987. Effect of Nitrogen and potassium on seed Production of Okra (Abelmoschus esculentus L.) in Calcareous soil. Indian J. Agron. 34: 425-427.

Mouneke CO, Asiegbu JE. 2003. Planting Density Effects on the Dry Matter Distribution and Yield of Okra in a Tropical Ultisol.-ASSET, 31: 59-72.

Muoneke CO, Asiegbu IE. 1996. Effect of planting density on the growth, dry matter accumulation, distribution and yield of okra in a tropical ultisol, p. 83-90. In: A. Adebanjo, S. F. Adedoyin, and D. A. Alabi (eds.), Proc. 14 ${ }^{\text {th }}$ HORTSON Conf., 1-4 Apr., Ago-Iwoye, Nigeria.

Odeleye FO, Odeleye OMO, Dada OA, Olaleye AO. 2005. The response of okra to varying levels of poultry manure and plant population density under sole cropping. Journal of Food, Agriculture and Environment Vol. 3(3-4): 68-74. www.world-food.net.

Olasantan FO. 1999. Nitrogen fertilization of okra (Abelmoschus esculentus) in an intercropping system with cassava (Manihot esculenta) and maize (Zea mays) in south-western Nigeria, Journal of Agricultural Science, Cambridge (1999), 133: 325334.

Olasantan FO. 2001. Optimum plant population for okra in a mixture with cassava (Manihot esculentus) and its relevance to rainy-season based cropping system in southern western Nigeria. J. of Agric. Science 136:207-214.

Pandey UC, Sing IJ. 1979. Effect of nitrogen, plant population and seed moisture regimes on seed production of okra (Abelmoschus Esculentus (L.) Moench.). Veg. Sci. 6(2): 81-91.

Rahman MA, Ferdousi A. 2012. Effect of NPK Fertilizers on Growth, Yield and Yield Attributes of Okra (Abelmoschus Esculentus L. Moench.). Bangladesh J. Bot. 41(2): 131-134.

Regmi R, Poudel S, Regmi RC, Shrestha J. 2020. Effect of Sowing Dates and Nitrogen Levels on Population of Okra Jassids (Amrasca biguttula biguttula Ishida) Indonesian Journal of Agricultural Research Vol. 03, No. 02, 2020, 127 135.

Reuterberg E, Kremkus F. 1951. Bestimmung von Gesamthumus und Alkalischen Humusstoffen im Boden', Z. Pflanzenernaehr. Düng. und Bodenkd. Verlag Chemie $\mathrm{GmbH}$. Weinheim.

Salau AW, Makinde EA. 2015. Planting Density and Variety on Okra Growth, Yield, and Yield Duration, International Journal of Vegetable Science, 21(4): 363-372.

Sarnaik DA, Baghel BSA, Baghel K. 1986. Response of okra seed crop to varying inter row and intra row spacing. J. Farming Syst. 2(3-4): 13-15.

Sharma F, Yadav S. 1996. Controlling ammonia volatilization from urea surface applied to sugar beet on a calcareous soil. Commun Soil Sci. 17: 9-10.

Sherestha FK. 1983. Effect of Spacing and Nitrogen Fertilizers on 'Pusa Sawani' Okra (Abelmoschus esculentus L.) in Nepal. Experimental Agriculture, 19: 239-242.

Singh P. 1979. Effect of Nitrogen, phosphorus and Potassium on Bhindi (Abelmoschus esculentus L.) progressive. Hort. India. 10: 21-30.

Singh P. 1990. Effect of spacing on okra. Indian J. Agron. 35: 439-441.

Singh P. 1995. Effect of various doses of nitrogen on seed yield and quality of okra (Abelmoschus esculentus L. Moench), Ann. Agric. Res., 16: 227-229.

Subbiah B, Asija GL. 1956. A rapid procedure for the estimation of available N in soils. Curr. Sci. 25: 259-260.

Verma VK, Pundrik KKC, Chauhan KS. 1970. Effect of different levels of N, P and $\mathrm{K}$ on vegetative growth and yield of okra. Punjab Hort. J. 10: 130-136.

Verma H, Singh S, Parihar MS, Nawange DD, Lovewanshi K. 2000. Effect of levels of nitrogen and gibberellic acid on growth, yield and quality of okra (Abelmoschus esculentus L. Moench). Journal of Pharmacognosy and Phytochemistry 2020; 9(4): 1165-1167. 
Vural H, Esiyok D, Duman I. 2000. Vegetable Production. Book, 440p.

Yoldas F, Ceylan S, Elmacı OL, Duman I, Duzyaman E, Özge M. 2018. The effects of different plant densities and nitrogen levels on some macro and micro element contents of okra. Selcuk J Agr Food Sci, 32(2): 163-169. doi: 10.15316/SJAFS.2018.80
Weiner J. 1990. Agrocology. Mc Fraw Hill Book Co. Inc., New York.

Zhang YH, Fan JB, Zhang YL, Wang DS, Huang QW, Shen QR. 2007. $\mathrm{N}$ accumulation and translocation in four japonica rice cultivars at different $\mathrm{N}$ rates. Pedosphere 17: 792-800. 